\title{
PENGARUH MODEL PEMBELAJARAN TEAMS GAMES TOURNAMENT (TGT) TERHADAP HASIL BELAJAR MATEMATIKA
}

\author{
Ai Solihah \\ Program Studi Teknik Informatika, Universitas Indraprasta PGRI \\ Email: faztasy@yahoo.com
}

\begin{abstract}
Abstrak
Tujuan penelitian ini adalah untuk menganalisis pengaruh hasil belajar matematika siswa kelas XI SMK Bina Taqwa Depok yang diajarkan dengan model pembelajaran Teams Games Tournament (TGT). Metode yang digunakan adalah metode eksperimen. Dalam penelitian ini, dua variabel tersebut adalah model pembelajaran Teams Games Tournament (TGT) dan hasil belajar matematika siswa. Sampel diambil dengan teknik random sampling. Sebelum melakukan uji hipotesis, terlebih dahulu dilakukan uji persyaratan data di antaranya: pengujian normalitas menggunakan uji Lilliefors dan pengujian homogenitas menggunakan uji fisher. Pengujian hipotesis menggunakan uji-t. Pada hasil penelitian ini menunjukkan bahwa hasil belajar matematika siswa yang diajarkan dengan model pembelajaran Teams Games Tournament (TGT) lebih tinggi daripada siswa yang diajarkan dengan model pembelajaran Student Teams-Achievement Divisions (STAD).
\end{abstract}

Kata kunci: Model Pembelajaran, Teams Games Tournament, Hasil Belajar Matematika

\section{Pendahuluan}

Peranan pendidikan sangat penting bagi setiap bangsa, karena kelangsungan hidup dan kemajuan suatu bangsa, khususnya bagi Negara yang sedang membangun ditentukan oleh maju tidaknya pendidikan, karena pendidikan merupakan upaya dalam meningkatkan kualitas sumber daya manusia. Menurut UU No. 20 tahun 2003 Bab II Pasal 3 pendidikan nasional berfungsi mengembangkan kemampuan dan membentuk watak serta peradaban bangsa yang bermartabat dalam rangka mencerdaskan kehidupan bangsa, bertujuan untuk berkembangnya potensi siswa agar menjadi manusia yang beriman dan bertakwa kepada Tuhan Yang Maha Esa, berakhlak mulia, sehat, berilmu, cakap, kreatif, mandiri, dan menjadi warga Negara yang demokratis serta bertanggungjawab.

Untuk mewujudkan tujuan pendidikan tersebut, maka diselenggarakanlah rangkaian pendidikan. Di antaranya pendidikan formal seperti sekolah, mulai dari tingkat kanak-kanak sampai perguruan tinggi. Kualitas dan pemerataan hasil pendidikan di Indonesia dinilai masih memprihatinkan, dilihat dari indikator hasil-hasil ujian yang masih berada di bawah angka standar dan sedikitnya anak yang memiliki kesempatan untuk belajar. Mendikbud mengatakan bahwa rata-rata nilai ujian SMK/SMA/MA mengalami kenaikan (Baswedan, 2015). Kehawatiran dengan dihapuskannya UN sebagai penentu kelulusan akan membuat anak-anak malas belajar tidak terbukti. Meskipun nilai rata-rata naik, sebagian besar nilai mata pelajaran mengalami penurunan salah satunya mata pelajaran matematika dari sebelumnya 60,4 menjadi 59,17 .

Di sekolah terdapat serangkaian bidang studi yang harus dikuasai oleh siswa salah satunya adalah matematika. Matematika adalah pelajaran yang sangat diperlukan di dalam dunia pendidikan. Dengan matematika, siswa dilatih untuk berpikir logis, sistematis, dan kritis. Selain itu, matematika melatih cara berpikir dan kemampuan penalaran siswa. Sehingga sangat berguna dalam menyelesaikan persoalan-persoalan dalam kehidupan sehari-hari. Matematika adalah salah satu bidang ilmu yang dijadikan sebagai mata pelajaran pokok di sekolah dari tingkat kanak-kanak sampai perguruan tinggi. Oleh karena itu, pelajaran matematika memegang peranan yang sangat penting dalam mengembangkan pola pikir bagi siswa. Hal ini sejalan dengan salah satu tujuan umum diberikannya matematika pada jenjang pendidikan dasar yaitu mempersiapkan siswa agar dapat menggunakan matematika dan pola 
pikir matematika dalam kehidupan sehari-hari dan dalam mempelajari berbagai ilmu pengetahuan.

Realita yang ada sekarang ini adalah pelajaran matematika merupakan pelajaran yang dianggap sulit oleh sebagian siswa. Keluhan-keluhan yang sering terdengar dari siswa adalah tentang banyaknya rumus serta aturan yang harus dihafal serta dimengerti dalam penggunaannya. Siswa menjadi malas belajar dan berlatih atau merasa tidak senang terhadap mata pelajaran matematika sehingga menyebabkan hasil belajar matematika selalu saja masih kurang memuaskan. Untuk mengatasi hal tersebut, telah banyak yang dilakukan guru baik dalam penyajian materi, pemilihan metode yang tepat dalam proses belajar. Hal ini dilakukan untuk meningkatkan hasil belajar matematika agar lebih baik lagi.

Dalam proses belajar mengajar anak didik merupakan subjek dan guru sebagai objek yang berperan secara aktif, dinamis dan interaktif. Salah satu komponen yang paling penting mendapatkan perhatian khusus adalah anak didik sebagai subjek yang berperan dalam kemajuan pendidikan. Peranan keluarga dan masyarakat sangatlah penting, untuk terbentuknya kemandirian pada diri siswa dan terbiasa untuk melakukan suatu kegiatan baik dilakukan sendiri maupun gotong royong dengan masyarakat.

Proses pembelajaran matematika di sekolah pada umumnya lebih bersifat klasikal yaitu guru berdiri di depan kelas sedangkan siswa duduk rapi di tempat masing-masing. Dalam sistem pembelajaran seperti ini, komunikasi yang terjadi cenderung satu arah yaitu guru aktif menerangkan sedangkan siswa duduk mendengarkan dan mencatat materi yang disajikan guru, dan akhirnya siswa hanya dijadikan sebagai penerima pengetahuan yang pasif. Hal ini bertentangan dengan pendapat (Aisyah, 2002), yang menyarankan agar guru melibatkan siswa secara aktif dalam pembelajaran dengan kegiatan diskusi, kerja kelompok, melakukan permainan, atau kegiatan laboratorium.

Berdasarkan uraian di atas, maka dalam kegiatan belajar matematika diupayakan terjadi interaksi aktif antar siswa baik secara fisik, intelektual maupun emosional. Dengan itu, model pembelajaran yang peneliti gunakan adalah model pembelajaran TGT dan STAD. Interaksi ini bisa dalam bentuk saling berdiskusi, bertanya dan bekerjasama dalam memahami atau mengerjakan tugas. Model pembelajaran STAD merupakan jenis pembelajaran kooperatif yang paling sederhana. Karena pada pelaksanaannya memberikan kesempatan siswa yang mempunyai kemampuan akademik menengah dan rendah untuk memahami materi pelajaran secara lebih baik.

Model pembelajaran TGT merupakan jenis pembelajaran kooperatif yang berkaitan dengan STAD. Dengan model pembelajaran TGT siswa yang pintar diusahakan dapat membantu siswa yang kurang, sedangkan bagi siswa yang relatif sudah menguasai materi diharapkan akan lebih memahami materi yang diajarkan. Dengan demikian, kegiatan belajar tidak hanya untuk siswa yang berkemampuan tinggi saja tetapi juga milik siswa yang berkemampuan rata-rata dan rendah. Keterlibatan siswa secara aktif dalam proses belajar mengajar tentu saja dapat menciptakan kondisi belajar menjadi lebih menyenangkan. Pemilihan model pembelajaran ini merupakan model pembelajaran alternatif yang menarik dan melibatkan siswa secara aktif, yang pada akhirnya diharapkan dapat meningkatkan hasil belajar matematika siswa.

Dengan demikian maka timbul permasalahan, "Apakah hasil belajar matematika siswa yang diajarkan dengan model pembelajaran Teams Games Tournament (TGT) lebih tinggi daripada siswa yang diajarkan dengan model pembelajaran Student Teams-Achievement Divisions (STAD)?"

\section{Tinjauan Pustaka}




\section{Hasil Belajar Matematika}

Menurut (Leonard, 2009), "Hasil belajar adalah kegiatan yang berhubungan dengan perubahan tingkah laku manusia, yang diakibatkan oleh pengalaman. Hal tersebut diperoleh dari pengetahuan, perilaku, dan keterampilan, melalui jalan latihan yang senantiasa di landasi oleh itikad dan tujuan tertentu". "Hasil belajar merupakan suatu puncak proses belajar" (Dimyati dan Mudjiono, 2002). Sementara (Suhendri, 2010a) mengatakan bahwa: "Hasil belajar adalah kemampuan-kemampuan yang dimiliki siswa setelah mengalami suatu proses belajar mengajar dan terjadi perubahan pada siswa tersebut ke arah yang lebih baik baik perubahan secara kognitif, afektif dan psikomotorik".

Menurut (Suriasumantri, 2007), "Matematika adalah bahasa yang melambangkan serangkaian makna dari pernyataan yang ingin kita sampaikan. Matematika dapat dikatakan sebagai suatu bahasa yang dapat diartikan dalam bentuk pernyataan-pernyataan yang ingin disampaikan. Setiap istilah dan simbol yang digunakan matematika haruslah merupakan hasil kesepakatan bersama secara cermat, agar konsep-konsep matematika dapat dimengerti oleh setiap orang dengan tepat. Konsep-konsep matematika disusun secara sistematis mulai yang sederhana sampai yang kompleks".

Menurut (Hudojo, 2003), "Matematika adalah suatu alat untuk mengembangkan cara berpikir". Karena itu matematika sangat diperlukan baik dalam kehidupan sehari-hari maupun dalam menghadapi kemajuan IPTEK sehingga matematika perlu dibekalkan kepada siswa pada jenjang pendidikan dasar maupun pada jenjang pendidikan menengah. Sementara itu, menurut (Jannah, 2011), "Matematika adalah suatu ilmu yang mempelajari bilangan, bangun, dan konsep-konsep yang berkenaan kebenarannya secara logika, menggunakan simbol-simbol yang umum serta aplikasi dalam bidang lainnya".

Dalam belajar matematika diperlukan pemahaman dan penguasaan materi terutama dalam membaca simbol, tabel dan diagram yang sering digunakan dalam matematika serta struktur matematika yang kompleks, dari yang konkret sampai yang abstrak, apalagi jika yang diberikan adalah soal dalam bentuk cerita yang memerlukan kemampuan penerjemahan soal ke dalam kalimat matematika dengan memperhatikan maksud dari pertanyaan soal tersebut.

Menurut (Suhendri, 2010b), "Hasil belajar matematika adalah kemampuan yang dimiliki seorang siswa setelah ia mendapat informasi berupa penjelasan materi pembelajaran matematika sehingga dapat berfikir secara kritis, logis, dan sistematis". Hasil belajar matematika dipengaruhi oleh adanya pengulangan dan penguatan. Apabila pengulangan dilakukan dengan frekuensi yang teratur dan disajikan dengan cara yang menarik maka akan memberikan dampak yang positif terhadap hasil belajar siswa. Demikian pula dengan penguatan yang diberikan guru akan memberikan kepuasan bagi siswa. Dan siswa cenderung untuk melakukan atau meningkatkan apa yang telah dicapainya.

Untuk mengetahui hasil belajar siswa maka perlu dilakukan penilaian atau evaluasi. Menurut (Arifin, 2009), "Penilaian hasil belajar adalah suatu proses atau kegiatan yang sistematis, berkelanjutan dan menyeluruh dalam rangka pengumpulan dan pengolahan informasi untuk menilai pencapaian proses dan hasil belajar siswa". Dari uraian di atas dapat disimpulkan bahwa hasil belajar matematika adalah hasil yang di dapat setelah mengalami proses pembelajaran matematika, dan bisa menilai seberapa jauh penguasaan siswa terhadap materi pembelajaran matematika, sehingga dapat membantu menyelesaikan permasalahan dalam kehidupan sehari-hari.

\section{Model Pembelajaran Teams Games Tournament (TGT)}

Menurut (Kurniasih, 2012), "Teams Games Tournament (TGT) adalah salah satu tipe atau metode pembelajaran kooperatif yang mudah di terapkan, melibatkan aktivitas seluruh siswa 
tanpa harus ada perbedaan status, melibatkan peran siswa sebagai tutor sebaya dan mengandung unsur permainan". Sedangkan menurut (Kusumandari, 2011) bahwa: "Teams Games Tournament (TGT)merupakan salah satu tipe pembelajaran kooperatif yang menempatkan siswa dalam kelompok-kelompok belajar yang beranggotakan 5-6 orang siswa yang memiliki kemampuan, jenis kelamin dan suku/ras yang berbeda". Menurut (Slavin, 2005), "Teams Games Tournament (TGT) pada awalnya dikembangkan oleh David DeVries dan Keith Edwards, ini merupakan metode pembelajaran pertama dari Johns Hopkins". Model pembelajaran Teams Games Tournament (TGT) adalah metode berkelompok yang mudah di terapkan, melibatkan aktivitas seluruh siswa tanpa harus ada perbedaan status.

Pada Teams Games Tournament (TGT) tidak terdapat kuis yang biasa digunakan dalam model pembelajaran kooperatif lain. Sebagai penggantinya, diadakan turnamen akademik setelah penyajian materi di kelas selesai. Dalam turnamen ini, siswa berkompetisi dengan anggota kelompok lain untuk mendapatkan poin yang akan disumbangkan pada skor kelompok.Turnamen memungkinkan siswa dari semua tingkat untuk menyumbangkan dengan maksimal skor-skor bagi kelompoknya jika mereka berusaha dengan maksimal, hal ini dikarenakan siswa berkemampuan akademik rendah dan tinggi mempunyai peluang yang sama untuk memperoleh prestasi, baik sebagai individu maupun anggota kelompok.

\section{Langkah-langkah Model Pembelajaran TGT}

Menurut (Sutirman, 2013a), langkah-langkah model pembelajaran TGT ialah:

a. Persentasi materi

Pada awal pembelajaran guru hendaknya memberikan motivasi, apersepsi dan menyampaikan tujuan pembelajaran. Kemudian guru menyampaikan materi pelajaran yang sesuai dengan indikator kompetensi yang harus dikuasai oleh siswa. Penyampaian materi dapat secara langsung melalui ceramah oleh guru, dapat pula dengan paket media pembelajaran audiovisual yang berisi materi yang sesuai.

b. Pembentukan kelompok

Setelah materi disampaikan oleh guru di depan kelas, selanjutnya dibentuk kelompokkelompok siswa. Kelompok terdiri dari 4-5 orang yang bersifat heterogen dalam hal prestasi belajar, jenis kelamin, suku, maupun lainnya. Setiap kelompok diberi lembar kerja atau materi dan tugas lainnya untuk didiskusikan dan dikerjakan oleh kelompok. Kesuksesan setiap anggota kelompok akan menjadi faktor keberhasilan kelompok.

c. Game turnamen

Setelah siswa belajar dan berdiskusi dalam kelompok, selanjutnya dilakukan permainan lomba (turnamen) yang bersifat akademik untuk mengukur penguasaan materi oleh siswa. Permainan yang dilakukan adalah semacam lomba cerdas cermat, dengan peserta perwakilan dari setiap kelompok. Soal dapat diberikan dalam bentuk pertanyaan lisan atau dalam bentuk kartu soal yang dipilih secara acak. Teknis pelaksanaan permainan turnamen ini adalah dimulai dengan guru merangking siswa dalam setiap kelompok. Selanjutnya menyiapkan meja turnamen sebanyak jumlah anggota dalam kelompok. Jika tiap kelompok beranggotakan 4 orang, maka disiapkan empat meja. Meja pertama diisi oleh siswa dengan rangking pertama di setiap kelompok, meja kedua diisi oleh siswa dengan rangking kedua di setiap kelompok, meja ketiga diisi oleh siswa dengan rangking ketiga di setiap kelompok, meja keempat diisi oleh siswa dengan rangking empat di setiap kelompok. Setiap siswa dapat berpindah meja berdasarkan prestasi yang diperolehnya pada turnamen. Siswa yang memperoleh nilai tertinggi pada setiap meja naik ke meja yang lebih tinggi tingkatnya. Siswa yang peringkat kedua tetap di meja semula, sedangkan siswa dengan nilai terendah turun ke meja yang lebih rendah tingkatnya.

d. Penghargaan kelompok

Perolehan skor anggota kelompok dirata-rata menjadi skor kelompok. Individu dan kelompok yang mencapai kriteria skor tertentu mendapat penghargaaan.

2. Kelebihan dan KelemahanModel Pembelajaran TGT

Menurut (Suarjana, 2000) dalam (Ekocin, 2011) menyatakan model pembelajaran Teams Games Tournament (TGT) memiliki beberapa kelebihan di antaranya: (a) lebih meningkatkan pencurahan waktu untuk tugas, (b) mengedepankan penerimaan terhadap 
perbedaan individu, (c) dengan waktu yang sedikit siswa dapat menguasai materi secara mendalam, (d) proses belajar mengajar berlangsung dengan keaktifan dari siswa, (e) motivasi belajar lebih tinggi, serta (f) mendidik siswa untuk berlatih bersosialisasi dengan orang lain. Di dalam TGT juga terdapat kelemahan di antaranya: bagi guru sulitnya mengelompokkan siswa yang mempunyai kemampuan heterogen dari segi akademis, serta adanya siswa berkemampuan tinggi yang kurang terbiasa dan sulit memberikan penjelasan kepada temannya.

Berdasarkan pendapat di atas, dapat disimpulkan model pembelajaran TGT adalah strategi pembelajaran yang menempatkan siswa dalam kelompok belajar yang beranggotakan 4-5 orang siswa yang memiliki tingkat kemampuan yang berbeda, dimulai dari guru menyampaikan tujuan pembelajaran serta menyajikan materi, dan siswa bekerja serta saling membantu dalam kelompok masing-masing untuk menyelesaikan tugas atau memahami materi pelajaran dengan bimbingan guru, dan di akhir pembelajaran diadakan turnamen untuk memastikan seluruh siswa menguasai materi pelajaran.

\section{Model Pembelajaran Student Teams-Achievement Divisions (STAD)}

Student Team-Achievement Divisions (STAD) adalah satu rangkaian teknik pengajaran yang dikembangkan dan diteliti di Universitas John Hoplins yang secara umum dikenal sebagai Kelompok Belajar Siswa. Menurut (Sharan, 2012), "STAD merupakan suatu metode generik tentang pengaturan kelas dan bukan metode pengajaran komprehensif untuk subjek tertentu". Menurut (Huda, 2013), "STAD adalah salah satu strategi pembelajaran kooperatif yang di dalamnya beberapa kelompok kecil siswa dengan level kemampuan akademik yang berbedabeda saling bekerja sama untuk menyelesaikan tujuan pembelajaran. Tidak hanya secara akademik, siswa juga dikelompokkan secara beragam berdasarkan kemampuan, gender, ras dan etnis". Teknik ini didasarkan pada gagasan tentang siswa-siswa yang belajar dalam kelompok belajar untuk memahami pelajaran.

Menurut (Sutirman, 2013b) "STAD merupakan metode umum dalam mengatur kelas untuk kegiatan pembelajaran". Menurut (Sharan, 2012), "Dalam Kelompok Belajar Siswa, tugas para siswa bukanlah melakukan sesuatu tetapi mempelajari sesuatu sebagai sebuah kelompok, di mana kerja kelompok dilakukan sampai semua anggota kelompok menguasai materi yang sedang dipelajari itu". Selanjutnya, menurut (Ngalimun, 2014) "STAD adalah salah satu model pembelajaran koperatif dengan sintaks: penghargaan, buat kelompok heterogen (4-5 orang), diskusikan bahan belajar-LKS-modul secara kolabratif, sajian-prestasi kelompok sehingga terjadi diskusi kelas, kuis individual dan buat skor perkembangan tiap siswa atau kelompok, umumnya rekor tim dan individual dan berikan reward.

\section{Langkah-langkah Model Pembelajaran STAD}

Menurut (Sutirman, 2013a), langkah-langkah model pembelajaran TGT ialah:

a. Persentasi materi

Pada awal pembelajaran guru hendaknya memberikan motivasi, apersepsi dan menyampaikan tujuan pembelajaran. Kemudian guru menyampaikan materi pelajaran yang sesuai dengan indikator kompetensi yang harus dikuasai oleh siswa. Penyampaian materi dapat secara langsung melalui ceramah oleh guru, dapat pula dengan paket media pembelajaran audiovisual yang berisi materi yang sesuai.

b. Pembentukan kelompok

Setelah materi disampaikan oleh guru di depan kelas, selanjutnya dibentuk kelompokkelompok siswa. Kelompok terdiri dari 4-5 orang yang bersifat heterogen dalam hal prestasi belajar, jenis kelamin, suku, maupun lainnya. Setiap kelompok diberi lembar kerja atau materi dan tugas lainnya untuk didiskusikan dan dikerjakan oleh kelompok. Kesuksesan setiap anggota kelompok akan menjadi faktor keberhasilan kelompok.

c. Kuis 
Setelah satu atau dua kali pertemuan, selanjutnya guru memberikan soal atau kuis kepada siswa untuk dikerjakan secara individual.

d. Skor kemajuan individu

Setiap siswa diberi skor awal berdasarkan nilai rata-rata yang diperoleh dari tes pertama atau tes sebelumnya. Selanjutnya, perolehan nilai siswa dibandingkan dengan nilai sebelumnya sehingga diperoleh skor atau nilai kemajuan individual. Kenaikan skor atau nilai siswa akan menjadi poin untuk kelompok mereka. Semakin baik kemajuan nilai yang diperoleh maka semakin tinggi poin yang dikumpulkan untuk kelompok.

e. Penghargaan kelompok

Perolehan nilai individu selanjutnya dirata-rata menjadi nilai kelompok. Apabila nilai rata-rata kelompok mencapai standar/kriteria tertentu maka kelompok tersebut akan mendapat penghargaan.

\section{Kelebihan dan KelemahanModel Pembelajaran STAD}

Menurut (Budairi, 2012) kelebihan model pembelajaran STAD di antaranya: (a) siswa bekerja sama dalam mencapai tujuan dengan menjunjung tinggi norma-norma kelompok, sehingga meningkatkan jiwa sosial masing-masing siswa, (b) siswa aktif saling membantu dan memotivasi semangat untuk berhasil bersama, (c) semua siswa aktif berperan sebagai tutor sebaya untuk lebih meningkatkan keberhasilan kelompok, sehingga setiap siswa mampu mengembangkan pemahaman dan penguasaan materi yang bersifat kognitif, psikomotoris, maupun afektif, (d) interaksi antar siswa seiring dengan peningkatan kemampuan mereka dalam berpendapat. Selain itu, STAD juga memiliki kelemahan, di antaranya: (a) membutuhkan waktu yang lebih lama untuk siswa sehingga sulit mencapai target kurikulum, (b) membutuhkan waktu yang lebih lama untuk guru sehingga pada umumnya guru tidak mau menggunakan pembelajaran kooperatif, (c) membutuhkan kemampuan khusus guru sehingga tidak semua guru dapat melakukan pembelajaran kooperatif, serta (d) menuntut sifat tertentu dari siswa, misalnya sifat suka bekerja sama.

Berdasarkan pengertian di atas dapat disimpulkan bahwa model pembelajaran STAD adalah salah satu model pembelajaran kooperatif yang penerapannya mirip dengan model pembelajaran TGT, tetapi STAD fokus pada komposisi kelompok berdasarkan kemampuan, ras, etnik dan gender sedangkan TGT hanya pada level kemampuan saja.

\section{Metodologi Penelitian}

Penelitian ini menggunakan metode eksperimen, untuk membandingkan hasil belajar matematika yang menggunakan model pembelajaran yang berbeda, yaitu model pembelajaran TGT dan STAD. Penelitian ini dilaksanakan di SMK Bina Taqwa Depok, dengan jumlah sampel 40 orang yang diambil dengan menggunakan teknik random sampling. Data dianalisis menggunakan uji-t, yang terlebih dahulu dilakukan perhitungan persyaratan analisis data, yaitu uji normalitas dan uji homogenitas.

\section{Hasil dan Pembahasan}

\section{Hasil Penelitian}

Deskripsi data penelitian berupa data kelompok TGT dan data kelompok STAD yang dapat diketahui secara lebih jelas oleh gambaran tabel di bawah ini:

Tabel 1. Rangkuman Data Deskriptif

\begin{tabular}{lcc}
\hline Deskripsi Data & TGT & STAD \\
\hline Banyaknya Data & 20 & 20 \\
Mean & 81,1 & 70,3
\end{tabular}




\begin{tabular}{lcc}
\hline Median & 82,5 & 70,36 \\
Modus & 84,07 & 69,9 \\
Simpangan Baku & 9,03 & 8,72 \\
\hline
\end{tabular}

Dari Tabel 1, menunjukan bahwa rata-rata tertinggi diperoleh kelompok siswa yang diajar dengan model pembelajaran TGT, dengan demikian dapat disimpulkan bahwa hasil belajar matematika siswa berada dalam kategori baik. Dan rata-rata terendah diperoleh kelompok siswa yang diajar dengan model pembelajaran STAD. Dengan demikian dapat disimpulkan bahwa hasil belajar matematika siswa berada dalam kategori cukup baik dan beragam.

Tabel 2. Rangkuman Hasil Belajar Matematika

\begin{tabular}{lccc}
\hline Deskripsi Data & TGT & & STAD \\
\hline Uji Prasyarat Analisis Data & & & \\
Uji Normalitas (Uji Lilliefors) & 0,1245 & & 0,1526 \\
Uji Homogenitas (Uji Fisher) & & 1,07 & \\
Uji Hipotesis & & & \\
Uji $t$ & & 3,86 & \\
\hline
\end{tabular}

Dari Tabel 2, diperoleh uji normalitas dengan model pembelajaran TGT $\mathrm{L}_{\text {hitung }}=0,1245$ dan $\mathrm{L}_{\text {tabel }}=0,190$ untuk $n=20$ taraf signifikan $\alpha=0,05$, sehingga $\mathrm{L}_{\text {hitung }}<\mathrm{L}_{\text {tabel }}$ yaitu $0,1245<$ 0,190 maka $\mathrm{H}_{0}$ diterima. Dapat disimpulkan bahwa data hasil belajar matematika siswa kelas eksperimen berasal dari sampel yang berdistribusi normal. Artinya nilai matematika yang diajarkan dengan model pembelajaran TGT berdistribusi normal. Sedangkan, uji normalitas dengan menggunakan model pembelajaran STAD $\mathrm{L}_{\text {hitung }}=0,1526$ dan $\mathrm{L}_{\text {tabel }}=0,190$ untuk $n=$ 20 taraf signifikan $\alpha=0,05$, sehingga $\mathrm{L}_{\text {hitung }}<\mathrm{L}_{\text {tabel }}$ yaitu $0,1526<0,190$ maka $\mathrm{H}_{0}$ diterima. Dapat disimpulkan bahwa data hasil belajar matematika siswa kelas kontrol berasal dari sampel yang berdistribusi normal. Artinya nilai matematika yang diajarkan dengan model pembelajaran STAD berdistribusi normal. Dan uji homogenitas $\mathrm{F}_{\text {hitung }}<\mathrm{F}_{\text {tabel }}$ yaitu $1,07<2,17$, maka $\mathrm{H}_{0}$ diterima. Oleh karena itu, dapat disimpulkan bahwa kedua data memiliki varian homogen. Serta uji hipotesis $t_{\text {hitung }}>t_{\text {tabel }}$ yaitu 3,86 >2,025 maka $\mathrm{H}_{0}$ ditolak dan $\mathrm{H}_{1}$ diterima. Dengan demikian dapat disimpulkan bahwa nilai rata-rata hasil belajar matematika siswa yang diajarkan menggunakan model pembelajaran TGT lebih tinggi daripada nilai rata-rata hasil belajar matematika siswa yang diajarkan menggunakan model pembelajaran STAD.

\section{Pembahasan Penelitian}

Berdasarkan hasil penelitian dan hasil pengujian hipotesis, maka terbukti bahwa terdapat pengaruh antara model pembelajaran TGT terhadap hasil belajar matematika. Hal ini menunjukkan bahwa hasil belajar siswa yang diajar dengan model pembelajaran TGT ternyata lebih tinggi daripada hasil belajar siswa yang diajar dengan model pembelajaran STAD. Perbedaan hasil belajar ini, terlihat dari nilai rata-rata hasil belajar yang diperoleh siswa dengan model pembelajaran TGT lebih tinggi dibandingkan dengan nilai rata-rata hasil belajar siswa yang diajar dengan model pembelajaran STAD, maka dalam penelitian ini guru matematika harus menciptakan metode belajar yang baik bagi siswa agar dapat dilakukan perlakuan yang tepat dalam proses kegiatan pembelajaran matematika khususnya pada pokok dimensi dua. Dengan demikian model pembelajaran TGT merupakan salah satu faktor yang mendukung dalam pencapaian hasil belajar matematika.

Berdasarkan uraian di atas, dapat dikatakan bahwa penggunaan model pembelajaran TGT dapat meningkatkan hasil belajar matematika siswa. Pernyataan ini didukung oleh penelitian yang dilakukan oleh (Citra Rahmayanti, 2007), menyatakan bahwa hasil belajar matematika siswa yang diajar menggunakan model pembelajaran kooperatif TGT lebih tinggi daripada hasil belajar matematika siswa yang diajar menggunakan metode latihan secara 
berkelompok. Selanjutnya, penelitian yang dilakukan oleh Erma Andhika Sari, menyatakan bahwa pembelajaran dengan menggunakan model TGT dapat meningkatkan kemampuan berbicara siswa, hal itu dapat dilihat dalam presentase keberhasilan siswa secara individu. Persentase ketuntasan siswa sebelum tindakan 59.37\%, siklus I persentase $61.72 \%$, siklus II persentase $80 \%$. Penelitian Pitriya Ningtiyas dan (Heri Siswaya, 2012), menyatakan bahwa metode kooperatif tipe TGT menggunakan modul dengan nilai rata-rata 79,69 lebih baik daripada yang menggunakan LKS dengan nilai rata-rata 70,78. Berdasarkan penelitian, terbukti bahwa model pembelajaran TGT dapat menumbuhkan motivasi siswa, sehingga siswa bersemangat dalam belajar. Karena model pembelajaran TGT siswa berkompetisi dengan kelompok-kelompok yang memiliki kemampuan yang setara, maka kompetisi dalam TGT terasa lebih fair dibandingkan dengan STAD. Dapat disimpulkan bahwa hasil belajar matematika yang menggunakan model pembelajaran TGT lebih tinggi daripada yang menggunakan model pembelajaran STAD.

\section{Simpulan dan Saran}

Berdasarkan hasil analisis yang telah dilakukan pada bagian terdahulu, dapat disimpulkan bahwa model pembelajaran TGT memiliki pengaruh terhadap hasil belajar matematika siswa pada pokok bahasan dimensi dua. Hal ini dapat dilihat dari hasil belajar matematika siswa yang diberi pengajaran TGT lebih tinggi daripada siswa yang diajarkan menggunakan model pembelajaran STAD. Lebih lanjut, berdasarkan uraian di atas maka saran yang penulis sampaikan terkait hasil penelitian, sebagai berikut:

a. Guru matematika diharapkan dapat menerapkan model pembelajaran TGT dalam pembelajaran dimensi dua. Agar proses pembelajaran efektif guru matematika harus membuat perencanaan pembelajaran secara matang dan cermat, selain itu juga harus melakukan persiapan.

b. Dalam pembelajaran, guru perlu memperhatikan sikap siswa dan menggunakan model pembelajaran yang bervariasi salah satunya adalah TGT. Hal ini dimaksudkan agar tidak menimbulkan kejenuhan siswa dalam mengikuti proses pembelajaran sehingga dapat mengubah sikap dan pandangan siswa menjadi lebih positif pada matematika sehingga akhirnya berdampak positif pada hasil belajarnya.

\section{Daftar Pustaka}

Aisyah, Nyimas. (2002). Mengembangkan Aktivitas Siswa dalam Pembelajaran Matematika Melalui Pembelajaran Kooperatif. Forum Kependidikan, Vol. 20, No.1, 57.

Arifin, Zainal. (2009). Evaluasi Pembelajaran Prinsip-Teknik-Prosedur. Bumi Siliwangi: PT Remaja Rosdakarya.

Baswedan, Anies. (2015). Tersedia: http://m.antaranews.com/berita/496321/mendikbud-ratarata-nilai-ujian-nasional-naik-03-poin.

Budairi, Ahmad. (2012). Kelebihan dan Kekurangan Student Team-Achievement Divisions.Tersedia:http://www.budairi.com/2012/11/pendidikan-kelebihan-dankekurangan.html\#axzz2VcpXIF4H.

Dimyati dan Mudjiono. (2002). Belajar dan Pembelajaran. Jakarta: PT Rineka Cipta.

Ekocin. (2011). Model Pembelajaran Teams Games Tournaments. Tersedia: http://ekocin.wordpress.com/2011/06/17/model-pembelajaran-teams-gamestournaments-tgt-2/.

Huda, Miftahul. (2013). Cooperative Learning. Yogyakarta: Pustaka Pelajar.

Hudojo, Herman. (2003). Pengembangan Kurikulum dan Pembelajaran Matematika. Malang: Universitas Negeri Malang.

Jannah, Raodatul. (2011). Membuat Anak Cinta Matematika dan Eksak Lainnya. Yogyakarta: Diva Press. 
Kemendiknas. (2012). UU Sistem Pendidikan Nasional. Bandung: Fokusindo Mandiri.

Kurniasih, Imas. (2012). Bukan Guru Biasa. Jakarta: Arta Pustaka.

Kumandari, Erna. (2011). Penerapan Pembelajaran Kooperatif TGT. Tersedia:http://biologi.fkip.uns.ac.id/wpcontent/uploads/2011/05/11.009-PenerapanPembelajaran-Kooperatif TGT.pdf.

Leonard. (2009). Pengaruh Model Pembelajaran Kooperatif Tipe Teams Games Tournament (TGT) terhadap Peningkatan Hasil Belajar Biologi pada Konsep Sistem Pencernaan Manusia. Faktor Exacta,Vol. 2, No.1, 83-97.

Ngalimun. (2014). Strategi dan Model Pembelajaran. Yogyakarta: Aswaja Pressindo.

Ningtiyas, Pitriya dan Heri Siswaya. Penggunaan Metode Kooperatif Tipe TGT Dilengkapi Modul dan LKS Ditinjau dari Aktivitas Siswa. Tersedia:http://ejournal.umm.ac.id, Vol. 3, No.1: 56.

Rahmayanti, Citra. (2007). Perbandingan Hasil Belajar Matematika antara Siswa yang Diajar Menggunakan Model Pembelajaran Kooperatif TGT dengan Metode Latihan secara Berkelompok di SMPN 150 Jakarta Timur. Jakarta: Skripsi Tidak Diterbitkan, Fakultas Matematika dan Ilmu Pengetahuan Alam Universitas Negeri Jakarta.

Sari, Erma Andhika. Penerapan Model TGT sebagai Upaya Meningkatkan Kemampuan Berbicara Siswa Kelas X-B SMA Ma'arif Pandaan-Pasuruan. Tersedia:http://jurnal.pasca.uns.ac.id, Vol. 12, No.2: 826. 24.

Sharan, Shlomo. (2012). Cooperative Learning. Yogyakarta: Familia Pustaka Keluarga.

Slavin, Robert E. (2005). Cooperative Learning: Teori, Riset dan Praktik. Bandung: Nusa Media.

Suhendri, Huri. (2010). Pengaruh Pemberian Tugas Pekerjaan Rumah terhadap Hasil Belajar Matematika Ditinjau dari Kemandirian Belajar Siswa. Exacta Jurnal Ilmiah Pendidikan \& Teknologi, Vol. 3, No.4, 361-363.

Suriasumantri, Jujun. (2007). Filsafat Ilmu Sebuah Pengantar Populer. Jakarta: Pustaka Sinar Harapan.

Sutirman. (2013). Media dan Model-model Pembelajaran Inovatif. Yogyakarta: GRAHA ILMU. 